Gulawentah: Jurnal Studi Sosial

ISSN 2528-6293 (Print); ISSN 2528-6871 (Online)

Vol. 4, No. 1, Juni 2020, Hal 68-76

Tersedia Online: http://e-journal.unipma.ac.id/index.php/gulawentah

\title{
Kemitraan Pemerintah Desa Mendak dan Perhutani dalam Pengelolaan Pariwisata
}

\author{
Renaldi Risky Pradana, dan Yusuf Adam Hilman* \\ Prodi Ilmu Pemerintahan, Universitas Muhammadiyah Ponorogo, Jl. Budi Utomo No.10 \\ Kabupaten Ponorogo 63471, Indonesia \\ Email: renaldirizki428@gmail.com ; *adam_hilman@umpo.ac.id
}

Naskah diterima: 19/5/2020; Revisi: 31/5/2020; Disetujui: 6/6/2020

\begin{abstract}
Abstrak
Tujuan penelitian ini adalah untuk mendeskripsikan tentang kerjasama kemitraan Pemerintah Desa Mendak Kecamatan Dagagan Kabupaten Madiun dengan Perhutani Lawu dalam pengelolaan pariwisata. Penelitian ini menggunakan pendekatan kualitatif deskriptif. Sumber data yang digunakan bersifat primer dan skunder. Teknik pengumpulan datanya dengan wawancara, observasi, dan pencatatan dokumen. Sedangkan analisis datanya dengan teknik analisis kualitatif model interaktif. Hasil penelitian menunjukkan bahwa Pola kemitraan Pemerintah Desa Mendak dengan pihak Perhutani Lawu Ds dalam bentuk inti-plasma. Pihak Perhutani sebagai penyedia lahan dan pihak Pemerintah Desa Mendak sebagai pelaksana dalam pengelolaan pariwisata Watu Rumpuk. Kemitraan yang terjalin saling menguntungkan dengan cara bagi hasil. Adapun pembagiannya Perhutani 30\%, Desa atau BUMDes 65\% serta LDMH $5 \%$. Selain itu, Kemitraan ini dapat membantu membuka lapangan pekerjaan dan mengurangi angka kemiskinan serta pengangguran di Desa Mendak dan mampu meningkatan pendapatan asli daerah (PAD).
\end{abstract}

Kata kunci: Kemitraan; Pengelolaan Pariwisata

\section{Partnership between Mendak Village Government and Perhutani in Tourism Management}

\begin{abstract}
The purpose of this study is to describe the partnership of the Mendak Village Government of Dagagan District, Madiun Regency and Perhutani Lawu in tourism management. This research uses a descriptive qualitative approach. Data sources used are primary and secondary. Data collection techniques with interviews, observation, and document recording. While the analysis of the data is with interactive model qualitative analysis techniques. The results showed that the pattern of partnership between Mendak Village Government and Perhutani Lawu Ds in the form of nucleus-plasma. Perhutani as the provider of land and the Mendak Village Government as the executor in the management of Watu Rusun tourism. Partnerships that are established are mutually beneficial by way of profit sharing. The distribution is Perhutani 30\%, Village or BUMDes 65\% and LDMH 5\%. In addition, the Partnership can help open jobs and reduce poverty and unemployment in the Mendak Village and be able to increase regional own-source revenue $(P A D)$.
\end{abstract}

Keywords: Partnership; Tourism Management

DOI: 10.25273/gulawentah.v5i1.6590

Some rights reserved. 


\section{Pendahuluan}

Pariwisata merupakan salah satu bagian yang begitu sangat penting bagi suatu negara. Dengan terdapatnya pariwisata, suatu negara atau daerah tempat obyek wisata tersebut dapat memberi pemasukan secara khusus atau pendapatan untuk daerah tersebut. Pariwisata dinyatakan sebagai pengaruh yang kuat dalam perkembangan wilayah maupun daerah sekitar obyek wisata. Partiwisata Indonesia diharapkan dapat berperan sebagai penentu dan katalisator pengembangan pembangunan wilayah secara bertahap, Oleh sebab itu sektor pariwisata Indonesia dijadikan sorotan. Industri pariwisata di Indonesia wajib mendapat atensi secara khusus oleh pemerintah baik pusat ataupun daerah dalam pengembangan pariwisatanya (Zaenuri, 2019).

Pengelolaan kegiatan pariwisata tentunya sangat dibutukan dalam upaya untuk menahan para wisatawan agar tinggal lebih lama di tempat tujuan wisata serta bagaimana wisatawan agar dapat membelanjakan uangnya sebanyak- banyaknya selama berwisata. semakin lama para wisatawan berada di tempat wisata maka akan menambah pengeluaran mereka, sehingga dapat memmbangkitkan perusahan jasa transportasi, akomodasi, hiburan, oleh-oleh ciri khas daerah dan jasa yang lainnya (Wardana, 2017). Oleh sebab itu pengelolaan dan pemanfaatkan potensi pariwisata yang dimiliki oleh daerah juga dikelola oleh tiap-tiap daerah. Begitu pula dengan Kabupaten Madiun yang memiliki salah satu wilayah yang memiliki potensi dan sumber daya alam yang dapat dikelola menjadi obyek wisata yaitu Desa Mendak Kecamatan Dagangan

Kabupaten Madiun memiliki kawasan andalan dalam sektor pariwisata berbasis pariwisata alam yaitu Watu Rumpuk, yang terletak di lereng gunung wilis, tepatnya di Desa Mendak Kecamatan Dagangan, Kabupaten Madiun. Wisata Watu Rumpuk dikelola oleh BUMDes dengan menggunakan sistem bagi hasil dengan perhutani yang memiliki lahan, tentunya dengan adanya wisata yang ada di lahan milik perhutani pasti ada kerjasama atau kemitraan yang terjalin antara pemerintah desa denga pihak perhutani sendiri, Watu Rumpuk juga sebagai pengelolaan konservasi alam, pariwisata, penelitian, serta pendidikan. Selain itu Watu Rumpuk juga terkenal sebagai salah satu daerah tujuan wisata alam yang digemari oleh para wisatawan, baik wisatawan lokal maupun wisatawan asing. Watu Rumpuk ditetapkan sebagai Desa Wisata melalui Perdes No.12/046.6/PKS-WST/LWU/DIVRE JATIM/2017. Adanya pariwisata watu rumpuk tentunya tidak bisa berkembang tanpa adanya kemitraan atau kerjasama yang terjalin antara pemerintah Desa Mendak dengan Perhutani. Kerjasama atau kemitraan yang terjalin tersebut nantinya akan memberikan manfaat antara kedua belah pihak tersebut, dan dapat menjadikan Desa Mendak berkembang sebagai desa wisata yang menjadi atau memiliki konsep ekonomi kreatif lokal, yang dapat meningkatkan kesejahteraan kehidupan yang ada di desa dan menjadi penggerak perekonomian masyarakat setempat.

Kunci dari keberhasilan dalam suatu usaha maupun kesempatan untuk meningkatkan peran usaha kecil ialah melalui kemitraan dengan pihak yang lain yang saling menguntungkan. Halnya sebagaimana yang presiden rencanakan program kerjasama atau kemitraan pada tanggal 14 januari 1991(Pardede, 2017). Program kemitraan lewat keterkaitan mitra usaha hal yang demikian mengontrol relasi kerjasama keterlibatan antar usaha besar dengan usaha menengah dan usaha kecil(M. Tohar, 2012). Dengan adanya kemitraan atau kerjasama ini dapat saling menguntungkan satu sama lain dari kedua belah pihak atau lebih yang berkomitmen untuk kerjasama, dengan demikian dengan adanya kemitraan atau kerjasama akan lebih membantu dalam menjalankan sebuah usaha maupun kegiatan yang lain.

Konteks dari kemitraan diatas yang dimaksud ialah dalam penelitian ini yakni kerjasama atau kemitraan pariwisata yang terjalin antara Pemerintah Desa Mendak dengan Perhutani dalam pengelolaan pariwisata watu rumpuk. Dalam menjalin kemitraan atau kerjasama hal yang perlu diperhatikan ialah harus adanya MoU, dimana didalam sebuah $\mathrm{MoU}$ terdapat kesepakatan bersama yang ditandatangani oleh kedua belahpihak, yang dapat dijadikan sebagai patokan, serta sebagai payung hukum dalam proses kemitraan maupun kerjsama yang 
terjalin nantinya. Serta hal lain yang perlu diperhatikan dalam menjalin sebuah kemitraan atau kerjasama ialah kepercayaan, dimana kepercayaan yang teguh bagi satu orang atau mitra merupakan bekal dasar dalam menjalani bisnis. Kemitraan yang direncanakan oleh dua pihak atau lebih dimulai atas dasar keputusan saling mempercayai. Hal yang harus dihindari dari kemitraan atau kerjasama ialah ketidak percayaan atau kecurigaan, Kegagalan dalam membentuk kemitraan biasanya dimulai dari langkah yg saling mencurigai serta perasaan yang saling tidak yakin antara satu sama yang lain (M. Tohar, 2012).

Apabila dihubungkan dengan teory governance, kemitraan dapat dikatakan sebagai suatu rangkaian kegiatan interaksi sosial politik pemerintah dengan warga atau masyarakat. Dengan demikian masyarakat atau pihak swasta dan pemerintah mempunyai hubungan/ikatan untuk bekerjasama atau bermitra dalam kegiatan kepemerintahan sebagai partisipasi, artisipasi ini yang akan menyebabkan kemitraan atau kerjasama antara pemerintah dengan masyarakat ataupun swasta (Mindarti, 2014). Dalam rangka pengembangan pariwisata, dimensi-dimensi collaborattive governance perlu dijadikan acuan dalam pelaksanaan praktik kemitraan. Dengan adanya pelaksanaan collaborattive governance, maka ada upaya untuk meningkatkan kualitas pelayanan dari suatu objek pariwisata karena adanya pengembangan dalam aspek sarana dan prasarana pariwisata yang memang ditujukan untuk kenyamanan para wisatwan atau pengunjung(Rotua \& Rudi, 2016). Collaborattive governance dalam pengembangan pariwisata pun juga dilakukan dalam upaya menjaga hubungan antar organisasi atau institusi. Karena memang dalam praktiknya collaborattive governance membutuhkan lebih dari satu organisasi atau institusi yang terlibat. Hubungan antar organisasi dalam collaborattive governance dapat pula memcahkan masalah pengembangan pariwisata yang dimungkinkan tidak mampu diselesaikan oleh satu organisasi atau instansi semata, akan tetapi dimungkinkan dapat terselesaiakan oleh peran institusi atau organisasi lain. Pelaksanaan collaborattive governance ini pun akan saling menguntungakan tiap organisasi atau institusi yang terlibat dalam pengembangan pariwisata. Hal ini lantaran tiap intitusi atau organisasi saling mengembangkan kapasitasnya dalam daya tarik kepariwisataannya dan mampu mecapai tujuannya dalam pengembangan pariwisata (Febrian, 2016).

Undang- Undang Republik Indonesia Nomor 9 Tahun 1995 tentang Usaha Kecil Pasal 8 ayat 1 kemitraan merupakan kerjasama usaha antara usaha kecil serta usaha menengah ataupun usaha besar diiringi pembinaan serta pengembangan oleh usaha menengah ataupun usaha besar dengan mencermati prinsip silih membutuhkan, silih menguatkan serta saling menguntungkan (Sulistyani, 2016). Terdapatnya kemitraan antara pemerintah Desa Mendak serta Perhutani diharapkan bisa menajaga serta melestarikan dengan terdapatnya kemitraan dalam pengelolaan obyek wisata diharapkan warga bisa berfungsi aktif dalam pengelolaan pembangunan wisata Watu Rumpuk. Sehingga pembangunan bisa dialami oleh warga lokal yang terletak di kawasan obyek pariwisata serta dapat tingkatkan Pendapatan Asli Daerah. Kemitraan jika diperhatikan dari segi etimologis disadur dari kata partnership, dan diadopsi dari kata partner. Di sini partner bisa diartikan sebagai "jodoh, pasangan, ataupun sekutu". Partnership juga diartikan sebagai persekutuan maupun perkongsian. Sedangkan kemitraan dimaknai sebagai sebagai wujud persekutuan antara dua belah pihak maupun lebih, yang menyusun suatu ikatan kerjasama atas dasar rasa saling memerlukan dan kesepakatan dalam rangka meningkatkan kapasitas serta kapabilitas di suatu tujuan tertentu atau, bidang usaha tertentu, sehingga bisa mendapatkan hasil yang bagus (Sulistyani, 2016).

Kerjasama atau kemitraan sendiri mempunyai arti yang hampir sama atau bisa dibilang mirip. Kemitraan menurut Kamus Besar Bahasa Indonesia adalah perihal hubungan (jalinan kerjasama) sebagai mitra (Suwondo, 2013). Sedangkan kerjasama menurut Kamus Besar Bahasa Indonesia ialah kegiatan atau usaha yang dilakukan oleh beberapa orang (lembaga, Pemerintah, dan lain sebagainya) untuk mencapai tujuan bersama. Menjalin kemitraan memiliki tujuan masing-masing yang dalam pelaksanaanya yaitu memiliki tujuan yang di antaranya untuk meningkatkan, mempermudah serta untuk mencari keuntungan dari kedua belah pihak dari yang melakukan kerjasama masing-masing kelompok, perusahaan, ataupun yang lainnya tersebut. Menurut Nurani (2017) model-model kemitraan meliputi; (a) kemitraan semu, (b) 
kemitraan mutualistik, dan (c) kemitraan melalui peleburan atau pengembangan. Ada suatu yang unik dari macam kemitraan ini, bahwa kedua belah pihak ataupun lebih sama memiliki rasa penting untuk melakukan kemitraan, namun kedua belah pihak yang bermitra belum tentu mengerti serta paham substansi yang diperjuangkan serta manfaatnya (Nurani, 2017). Manfaat saling silang antara pihak yang melaksanakan kemitraan bisa diperoleh sehingga sekaligus saling mendukung satu dengan yang lain (Wahyudi, 2016). Sementara dalam kemitraan pengembangan dua pihak ataupun lebih bisa melakukan konjungsi dalam rangka meningkatkan keahlian masing-masing. Pola kemitraan secara umum dapat diartikan sebagai bentuk kerja sama yang saling menguntungkan antara dua pihak atau lebih untuk mencapai tujuan bersama. Pola kemitraan ialah bentuk penerapan kerjasama dalam kerangka model kemitraan. Pola yang diteliti mengacu pada teori pola kemitraan usaha kecil, pemberdayaan masyarakat. Pola Kemitraan usaha kecil terdiri dari: intiplasma, subkontrak, dagang umum, keagenan dan waralaba. Kemitraan dalam pemberdayaan warga meliputi pola investasi publik ataupun swasta (Oktaviyanti, 2013).

Pariwisata ialah suatu kegiatan dari yang dilaksanakan oleh wisatawan (orang yang sedang berwisata) ke suatu daerah atau tujuan tempat wisata di luar keseharian atau dihari libur dan lingkungan daerahtempat tinggal untuk melaksanakan persinggahan sementara waktu dari daerah tempat tinggal, yang didukung sebagian kebutuhan tanpa ada maksud untuk mencari nafkah atau bekerja dan melainkan atas dasar keperluan untuk mencari kesenangan semata, dan serta untuk merasakan bermacam-macam hiburan yang bisa menghilangkan lelah dan menciptakan suatu travel experience dan hospitality service (Zakaria \& Suprihardjo, 2014). Adapun macam-macam pariwisata sebagai berikut

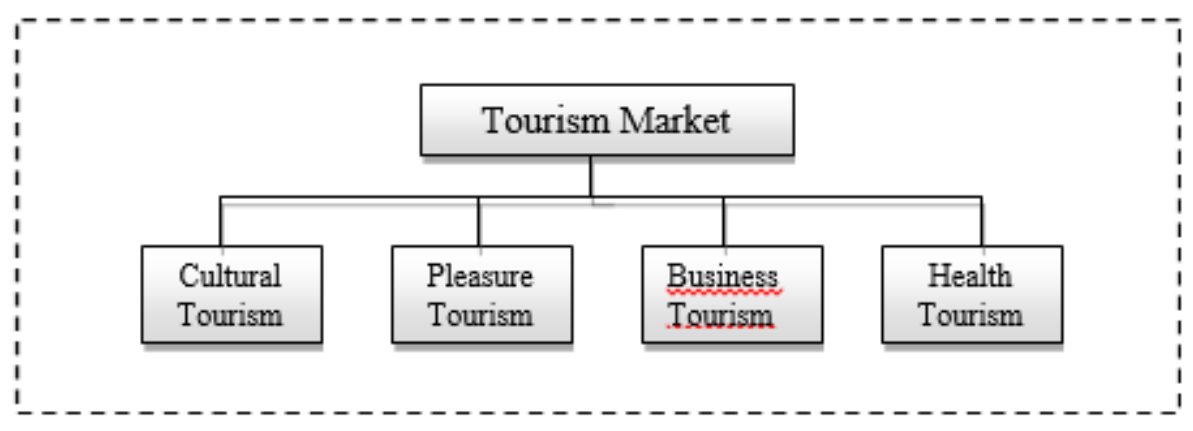

Gambar 1. Pembagian macam-macam pariwisata

Sumber : (Zakaria \& Suprihardjo, 2014)

Tipe pariwisata kebudayaan (cultural tourism) ini ditandai dengan adanya rangkaian motivasi, seperti kemauan untuk belajar di sentra pendidikan dan riset, mempelajari adatistiadat, kelembagaan, dan sistem hidup masyarakat yang tidak sama antara satu dengan yang lain atau berbeda-beda, mengunjungi monumen bersejarah, peninggalan masa lalu, kesenian serta keagamaan, tarian rakyat, teater, festival seni musik dan lain-lain (Djumani, 2013). Tipe pariwisata untuk menikmati perjalanan (pleasure tourism), tipe pariwisata ini dilaksanakan oleh orang-orang yang meninggalkan daerahnya untuk mencari udara segar, berwisata, memenuhi kehendak berkeingin-tahunya, mengendorkan ketegangan saraf, mencari pandangan sesuatu yang baru, menikmati kecantikan alam, mengenal hikayat rakyat setempat, serta memperoleh ketenangan (Raman et al., 2015). Tipe pariwisata untuk urusan bisnis atau usaha dagang (business tourism) jenis pariwisata ini merupakan wujud profesional travel atau perjalanan sebab ada kaitannya dengan profesi ataupun jabatan yang tak memberikan terhadap seseorang untuk menentukan tujuan ataupun waktu perjalanan. Pariwisata kesehatan (healt tourism) dimana jenis pariwisata yang satu ini maksudnya ialah perjalanan seseorang wisatawan dengan tujuan untuk menukar kondisi dan lingkungan tempat tinggal sehari-hari dimana dia berdomisili 
demi kepentingan beristirahat dalam arti jasmaniah dan rohani, dengan mengunjungi daerah peristirahatan seperti tempat sumber mata air panas yang mengandung mineral yang bisa menyembuhkan, daerah yang memiliki udara yang meneyehatkan atau daerah-daerah yang memberikan fasilitas kesehatan lainnya (Kuswanti, 2011).

\section{Metode Penelitian}

Metode penelitian yang digunakan dalam penelitian kualitatif deskriptif. Penelitian dilaksanakan di Desa Mendak Kecamatan Dagangan Kabupaten Madiun. Sumber data yang digunakan bersifat primer dan skunder. Metode pengumpulan data primer dilakukan dengan cara wawancara mendalam dengan informan yang dianggap dapat mewakili menjawab pertanyaan yaitu dapat dilihat di tabel 1 . Wawancara tersebut bertujuan untuk menggali bentukbentuk kemitraan pemerintah desa mendak dengan perhutani dalam pengelolaan pariwisata. Pengumpulan data sekunder dilakukan apabila informasi yang diperoleh belum bisa digunakan sebagai sesuatu informasi atau data yang bermutu serta diperlukan untuk menunjang fakta fakta yang didapatkan dari wawancara mendalam. Pengumpulan data skunder yang dilakukan adalah survei instansi serta kajian literatur(Septiani \& Asnawi, 2015). Sedangkan data yang diperoleh dianalisis dengan teknik analisis kualitatif model interaktif.

\section{Hasil dan Pembahasan}

\section{Latar belakang kemitraan pemerintah desa Mendak dengan Perhutani Lawu}

Latar belakang adanya kemitraan ialah pada tahun 2011 masyarakat desa Mendak yang sebagian besar menjadi petani cengkeh mengalami musibah dimana semua pohon cengkeh yang ada di desa Mendak terserang wabah, hampir semua pohon cengkeh mati, tidak hanya itu pada tahun 2015 Desa Mendak mengalami musibah bencana tanah longsor yang mengakibatkan semakin terpuruknya perekonomian masyarakat desa Mendak, dari situlah masyarakat berinisiatif untuk mengembangkan potensi wilayah yang ada, hingga disetujui oleh masyarakat untuk membuat obyek wisata yang ada di desa.

Mengingat wilayah yang dijadikan destinasi wisata miliknya Perhutani Lawu, maka pemerintah desa berkomnikasi untuk melaksanakan usaha kemitraan. Upaya pemerintah desa Mendak direspon positif yang dimanivestasikan dalam MoU Nomor: 22/044.6/PKSWST/LWU/DIVRE JATIM/2018. Sedangkan dasar dasar hukum dalam pembuatan wisata yaitu tertuang dalam Perdes Mendak Nomor 11 Tahun 2016. Selain itu juga mengacu pada UndangUndang Republik Indonesia Nomor 9 Tahun 1995 Tentang Usaha Kecil Pasal 8 Ayat 1 kemitraan merupakan kerjasama usaha antara usaha kecil serta usaha menengah ataupun usaha besar. Pemerintah desa Mendak sebagai pelaku usaha kecil dan Perhutani sebagai Pelaku usaha besar diiringi pembinaan serta pengembangan oleh usaha besar dengan mencermati prinsip saling membutuhkan serta, saling menguatkan dan saling menguntungkan (Sulistyani, 2016). Yang mendasari pihak perhutani dalam bermitra dengan pemerintah desa mendak ialah dimana pihak perhutani sendiri memiliki progam yang disebut dengan PHBM yaitu pengelolaan hutan bersama masyarakat (Khaidir, 2019).

\section{Pola kemitraan yang terjalin antara pemerintah desa mendak dengan perhutani}

Pengelolaan Hutan Bersama Masyarakat (PHBM) adalah sesuatu sistem kegiatan pengelolaan hutan dengan pola berkolaborasi yang bersinergi antara Perum Perhutani dengan Masyarakat Desa Hutan (MDH) atau dengan stake holder yang terkait (Rizal et al., 2014). Sistem kemitraan yang kami terapkan dalam kerjasama dengan pihak desa mendak ialah menggunakan sistem kerjasama bagi hasil dari pendapatan pariwisata nantinya yang sudah diatur dalam Surat Perjanjian kerjasama (Khaidir, 2019). Pola Kemitraan yang terjalin antara pemerintah desa mendak dengan pihak perhuntani berjala dengan pola bagi hasil dari pendapatan wisata yang telah disepakati bersama dalam surat perjanjian kerjasama MoU, dimana pembagian hasil antara lain pihak Perhutani 30\%, Desa atau BUMDes 65\% serta 
LDMH 5\%. Dengan adanya kemitraan yang terjalin antara Pemerintah Desa Mendak dengan perhutani banyak diharapkan dapat membantu membuka lapangan pekerjaan dan mengurangi angka kemiskinan serta pengangguran di Desa Mendak dan juga diharapkan mampu meningkatan pendapatan asli daerah (PAD).

Proses adanya kemitraan Pemerintah Desa Mendak Dengan Perhutani Lawu Ds dalam pengelolaan pariwisata ialah dimana tahap awal yang harus dilakukan ialah pembuatan perdes wisata desa kemudian pembuatan Sk pokdarwis dan dilanjut pembuatan proposal dan langkah selanjutnya ialah pembuatan kesepakatan bersama atau MoU, dan langkah yang terakhir adalah penandatanganan surat perjanjian kerjasama atau PKS antara kedua belah pihak. Proses pengajuan MoU dengan pihak perhutani ialah dimana pertama dilakukan pembentukan Perdes terkait pemetaan pembangunan potensi wisata terlebih dahulu kemudian Dibentuk SK Pokdarwis lalu dimasukan dalam pengelolan oleh BUMDes(Cholifah, 2019a) Dalam proses kemitraan yang terjalin yang harus diperhatikan ialah pertama Pertama pengajuan proposal oleh pihak desa, kedua pihak perhutani bagian pengembangan usaha mengadakan cek ke lapangan terkait kelayakan untuk dikembangkan sebagai tempat wisata, selanjutnya pembuatan kesepakatan bersama atau MoU, dam yang terakhir adalah penandatanganan Pks kedua belah pihak (Khaidir, 2019). Tata kelola komunitas kadang-kadang digunakan untuk merujuk partisipasi masyarakat, keterlibatan dan pengambilan keputusan dalam masalah publik dan terkait dengan istilah-istilah seperti pemerintahan lokal, tata kelola sosial, tata kelola jaringan dan partisipatif pemerintahan (Halsall, 2012).

\section{Sistem monitoring yang dilakukan oleh pihak perhutani dalam pengelolaan pariwisata}

Monitorong yang dilakukan oleh perhutani ialah dilakukan dalam waktu satu bulan sekali dimana meliputi monitoring jumlah pengunjung saja tapi untuk monitoring yang dilakukan oleh pihak dinas pariwisata kabupaten madiun yaitu meliputi jumlah pengunjung, perkembangan pariwisata, UMKMnya serta pengevaluasian(Cholifah, 2019a). Monitoring yang kami lakukan dalam pengelolaan pariwisata watu rumpuk itu meliputi monitoring penjualan tiket pengunjung, serta monev dari pengawasan terhadap menjaga keadaan wilayah hutan, dan dilakukan secara berkala, 1 bulan sekali(Khaidir, 2019).

Tabel 2. Jumlah Kunjungan Wisatawan Wisata Watu Rumpuk Tahun 2018-2019

\begin{tabular}{llll}
\hline No. & Bulan & Tahun & Kunjungan Wisatawan \\
\hline 1. & Juni - Des & 2018 & 84.035 Orang \\
\hline 2. & Jan - Mrt & 2019 & 20.345 Orang \\
\hline
\end{tabular}

Sistem monitoring yang dlakukan oleh Perhutani diamana monitoring yang dilakukan oleh pihak Perhutani meliputi jumlah penjualan tiket pengunjung, serta monev dari pengawasan terhadap menjaga keadaan wilayah hutan, tidak hanya perhutani monitoring wisata watu rumpuk juga dilakukan oleh Pemerintah Kabupaten Madiun melalui Dinas Pariwisata, Pemuda dan Olahraga selalu melakukan kegiatan monitorong yang dilakukan dalam satu bulan sekali, kegiatan monitoring ini rutin dilakukan untuk mengetahui jumlah pengunjung, perkembangan obyek wisata serta, perkembangan UMKM yang ada dan pengevaluasian.

Tabel 3. Jumlah Pendapatan Wisata Watu Rumpuk Tahun 2018-2019

\begin{tabular}{ccccccc}
\hline Bulan & Tahun & Omset & PERHUTANI & LMDH & BUMDES & $\begin{array}{c}30 \% \\
\text { Bumdes } \\
\text { (Desa) }\end{array}$ \\
\hline $\begin{array}{c}\text { Juni }- \\
\text { Des }\end{array}$ & 2018 & 384.562 .500 & 135.954 .200 & 14.751 .300 & 233.857 .000 & 70.157 .100 \\
\hline
\end{tabular}




$\begin{array}{llllll}\text { Jan-Mrt } \quad 2019 \quad 123.830 .200 & 48.039 .000 & 4.526 .700 & 71.264 .500 & 21.379 .350\end{array}$

Harapan dari adanya kemitraan antara pemerintah desa mendak dengan pihak perhutani dalam pengelolaan pariwisata ialah mampu sebagai pengungkit perekonomi masyarakat atau penggerak perekonomian masyarakat, selain itu harapannya adalah bisa menambah atau meningkatkan pendapatan asli daerah (PAD), juga serta untuk meningkatkan nilai ketahanan ekonomi lokal, tidak hanya itu juga diharapkan bisa menambah kesadaran masyarakat dan pengunjung wisata dalam menjaga kelestarian hutan, serta kebersihan lingkungan. Sektor pariwisata menjadi salah satu sector yang diharapkan dapat meningkatkan pendapatan asli daerah (Saputra et al., 2019).

\section{Faktor penghambat kemitraan dalam pengelolaan pariwisata Watu Rumpuk}

Hambatan atau kendala dalam menjalin kemitraan pengelolan pariwisata ini ialah dimana masalah yang utama ialah masih kurang intensifnya komunikasi antara pihak pemerintah desa mendak dengan pihak perhutani, dan mengenai kurangnya anggaran dalam pengembangan pariwisata, serta masih adanya masyarakat yang kurang paham akan kesadaran tetang pentingnya kelestarian hutan dan masalah masalah kecil lainnya seperti sempitnya akses jalan menuju obyek wisata watu rumpuk, selain itu terbatasanya lahan parkir. Rencana yang dilakukan oleh Pemerintah Desa Mendak dalam hal kemitraan dengan pihak Perhutani Lawu DS ialah penambahan luas kawasan wisata yang tadinya hanya 2,5 hektar akan ditambah menjadi 12 hektar, selain itu Surat Perjanjian Kerjasama yang semulanya hanya berlaku dalam kurun waktu hanya 1 tahun akan ditambah menjadi 10 tahun, serta dalam pembangunan wisata akan terus dilakukan dan terus diperbarui dimana untuk menarik minat wisatawan agar kembali berkunjung.

Beberapa hal yang menjadi penghambat dalam pengembangan pariwisata watu rumpuk yang masih dirasa yaitu masalah anggaran atau biaya mas yang terbatas serta akses jalan menuju lokasi wisata yang sempit dan lahan parkir yang kurang (Cholifah, 2019a). Hambatan yang menjadi kendala kami dalam menjalin kemitraan dengan pihak pemerintah desa mendak dalam pengelolaan pariwisata yaitu dimana masih kurang intensifnya komunikasi dari pihak desa serta masih adanya masyarakat yang kurang paham akan pentingnya kelestarian hutan (Khaidir, 2019). Hambatan atau kendala dalam menjalin kemitraan pengelolan pariwisata ini ialah dimana masalah yang utama ialah masih kurang intensifnya komunikasi antara pihak pemerintah desa mendak dengan pihak perhutani. Perlu dibangunnya tingkat kesadaran tertinggi masyarakat dalam bentuk citizen control untuk dapat meningkatkan pariwisata yang berbasis pengelolaan bermitra (Purmada et al., 2016). Mengenai kurangnya anggaran dalam pengembangan pariwisata, serta masih adanya masyarakat yang kurang paham akan kesadaran tetang pentingnya kelestarian hutan dan masalah masalah kecil lainnya seperti sempitnya akses jalan menuju obyek wisata watu rumpuk, selain itu terbatasanya lahan parkir. Investasi pemerintah hal ini pemerintah desa perlu didukung langsung oleh pemeritah kabupaten, dikarenakan pariwisata menjadi komoditi yang bagus dalam peningkatan kesejahteraan warga (Aziz \& Abidin, 2019). Membangun sebuah destinasi wisata yang berangkat dari kearifan lokal untuk menjadi sebuah wisata nasional maupun internasional membutuhkan waktu, kerjakeras dan kerjasama oleh seluruh pemangku kepentingan.

\section{Simpulan}

Pola kemitraan Pemerintah Desa Mendak dengan pihak Perhutani Lawu Ds dalam bentuk inti-plasma. Pihak Perhutani sebagai penyedia lahan dan pihak Pemerintah Desa Mendak sebagai pelaksana dalam pengelolaan pariwisata Watu Rumpuk. Kemitraan yang terjalin saling menguntungkan dengan cara bagi hasil. Adapun pembagiannya Perhutani 30\%, Desa atau BUMDes $65 \%$ serta LDMH $5 \%$. 


\section{Daftar Pustaka}

Aziz, R. F., \& Abidin, A. Z. (2019). Pengelolaan Perum Perhutani dalam Mengembangkan Wisata Pantai Indah (Studi di Desa Tambak Rejo, Kecamatan Sumbermanjing Wetan, Kabupaten Malang). Jurnal Respon Publik, 13(6), 87-96.

Cholifah, N. (2019a). Hasil Wawancara.

Cholifah, N. (2019b). Profil desa wisata mendak.

Djumani, V. R. (2013). ANALISIS MANAJEMEN KAWASAN PERSIAPAN OBJEK WISATA EKOLOGI TAMAN HUTAN MONYET DI TELUK BETUNG UTARA. Fakultas ISIP.

Febrian, R. A. (2016). Collaborative Governance dalam Pembangunan Kawasan Perdesaan (Review of the Draft and Regulation). Wedana: Jurnal Pemerintahan, Politik Dan Birokrasi, 2(1), 200-208. http://journal.uir.ac.id/index.php/wedana/article/view/1824 diakses pada tanggal 5 April 2019 pukul 02:55 WIB

Halsall, J. (2012). Community Governance - Where did it all go Wrong? Journal of Administration and Governance JOAAG, 7(2), 1-8.

Khaidir. (2019). Hasil wawancara.

Kuswanti, A. (2011). Universitas Sumatera Utara. 1987, 5-30. https://doi.org/10.1007/s13398014-0173-7.2

M. Tohar. (2012). Aspek-Aspek Financial Usaha Kecil dan Menengah,. 9, 20-46.

Mindarti, mohammad rizal nur zain. saleh soeaidy. lely indah. (2014). Kemitraan Antara KPH PERHUTANI dan LMDH Dalam Menjaga Kelestarian Hutan ( Studi pada Desa Jengglungharjo Kecamatan Tanggunggunung Kabupaten Tulungagung ). Jurnal Administrasi Publik, 2(2), 210-216.

Nurani, A. Y. F. A. S. F. (2017). Pelaksanaan Program Kemitraan Pemerintah Dan Masyarakat Dalam Penataan Lingkungan Permukiman Berbasis Komunitas. Journal of Chemical Information and Modeling, 53(9), 1689-1699. https://doi.org/10.1017/CBO9781107415324.004

Oktaviyanti, S. S. (2013). Pariwisata j. Jurnal Nasional Pariwisata, 5(3), 154-167.

Pardede, P. josua. (2017). Pola Kemitraan dalam Praktek Tanggungjawab Sosial Perusahaan. Jurnal Kebijakan Dan Administrasi Publik, 11 .

Purmada, D., Wilopo, W., \& Hakim, L. (2016). Pengelolaan Desa Wisata dalam Prespektif Community Based Tourism (Studi Kasus pada Desa Wisata Gubugklakah, Kecamatan Poncokusumo, Kabupaten Malang). Jurnal Administrasi Bisnis S1 Universitas Brawijaya, 32(2), 15-22.

Raman, R., Malik, I., \& Hamrun, H. (2015). Kemitraan Pemerintah Daerah Dengan Kelompok Masyarakat Dalam Pengelolaan Hutan Mangrove Di Desa Tongke-Tongke Kabupaten Sinjai. Otoritas : Jurnal Ilmu Pemerintahan, 5(2). https://doi.org/10.26618/ojip.v5i2.123

Rizal, M., Zain, N., Soeaidy, S., Mindarti, L. I., Publik, J. A., Administrasi, F. I., \& Brawijaya, U. (2014). Kemitraan Antara KPH PERHUTANI dan LMDH Dalam Menjaga Kelestarian Hutan ( Studi pada Desa Jengglungharjo Kecamatan Tanggunggunung Kabupaten Tulungagung ). 2(2), 210-216.

Rotua, K., \& Rudi, S. (2016). Peran Pemerintah Daerah dalam Pengembangan Pariwisata Alam dan Budaya di Kabupaten Tapanuli Utara. JPPUMA: Jurnal Ilmu Pemerintahan Dan Sosial Politik UMA (Journal of Governance and Political Social UMA), 4(1), 79-96. 
Saputra, G. R., Zaenuri, M., Purnomo, E. P., \& Fridayani, H. D. (2019). Kemitraan Pengelolaan Pariwisata Dalam Meningkatkan Pendapatan Asli Daerah Kabupaten Tasikmalaya Tahun 2017. Kemudi: Jurnal Ilmu Pemerintahan, 03(1), 298-341. https://ojs.umrah.ac.id/index.php/kemudi/article/view/896/594

Sulistyani, A. T. (2016). Ambar Teguh Sulistiyani. Kemitraan dan Model-Model Pemberdayaan . Gaya Media. Yogyakarta. 2004. hal. 129. Konsep Kemitraan.

Suwondo, H. R. B. S. (2013). Kemitraan Lembaga Pemberdayaan Masyarakat Desa dengan Kepala Dessa dalam Perencanaan Pembangunan Desa (Studi Kasus di Desa Sumber Ngepoh Kecamatan Lawang Kabupaten Malang) Hasyemi Rafsanzani, Bambang Supriyono, Suwondo. Jurusan Administrasi Publik, 1(4), 67-72.

Wahyudi, D. (2016). Produktivitas Pengelolaan Objek Wisata Green Canyon Oleh Dinas Pariwisata Perindustrian Perdagangan Dan Usaha Mikro Kecil Menengah Dalam Upaya Menarik Minat Wisatawan Di Kabupaten Pangandaran. Moderat: Jurnal Ilmu Pemerintahan, 2.

Wardana. (2017). Potensi Dan Strategi Pengembangan Pariwisata Di Kabupaten Pesisir Barat. $1-78$.

Zaenuri., gustian riadi saputra. M. E. P. P. H. D. F. (2019). Kemitraan Pengelolaan Pariwisata Dalam Meningkatkan Pendapatan Asli Daerah Kabupaten Tasikmalaya Tahun 2017. Kemudi: Jurnal Ilmu Pemerintahan, 03(1), 298-341.

Zakaria, F., \& Suprihardjo, D. (2014). Konsep Pengembangan Kawasan Desa Wisata di Desa Bandungan Kecamatan Pakong Kabupaten Pamekasan. Jurnal Teknik Pomits, 3(2), C245C249. https://doi.org/2337-3520 